\title{
Review of Against the Tide: Immigrants, Day- Laborers, and Community in Jupiter, Florida.
}

\author{
GUSTAVO BARAHONA-LÓPEZ \\ University of California at Santa Barbara, USA
}

Against the Tide: Immigrants, Day-Laborers, and Community in Jupiter, Florida. Written by Sandra Lazo de la Vega \& Timothy J. Steigenga.

The University of Wisconsin Press, (2013)

ISBN: 9780299291037

As noted by Sandra Lazo de la Vega and Timothy J. Steigenga, the authors of Against the Tide: Immigrants, Day-Laborers, and Community in Jupiter, Florida, immigration is among the most contentious issues in contemporary politics. With comprehensive immigration reform currently being negotiated in Congress, this book adds an important perspective to the discourse around migration. As migrants begin to settle in "new" locations all over the United States, local governments attempt to deal with the conflicts that arise in various ways. Lazo de la Vega and Steigenga give an account of one particular response, namely, the creation of El Sol, Jupiter's Neighborhood Resource Center. By presenting one way to address migration-related issues in a systemic, human-oriented manner, the authors make a timely intervention in immigration policy discussions with public policy impacts nationwide.

The book argues that building day labour centers through broad-based public/private coalitions is an effective way of dealing with the tensions caused by upsurges in migration. Lazo de la Vega and Steigenga show that investing in community centers and making an effort to build bonds with migrant communities are far more effective ways of addressing local qualityof-life issues than depending on purely punitive local ordinances ${ }^{1}$. The book follows the emergence of a coalition seeking solutions for standard-of-living issues in Jupiter, Florida and the successful outcome of its organizational efforts; El Sol. Jupiter was a town with relatively few immigrants for most of its history. However, in the 1990's and 2000's, rapid economic growth 
in the town created a demand for construction workers and other service sector labourers that were met mostly by Guatemalan migrant workers. The informal day-worker hiring site on Center Street became a flashpoint of resident concerns over the demographic changes occurring in Jupiter. After much deliberation, El Sol opened in 2006 through the efforts of a huge coalition which included, but was not limited to, Saint Peter Catholic Church, Corn Maya Inc., Catholic Charities, neighbourhood residents, the Immigration Issues Committee of People Engaged in Active Community Efforts (PEACE), the Jupiter Democratic Club, Wilkes Honors College of FAU, the Guatemalan consulate, a huge number of volunteers, and many politicians and staff members from the local government. Lazo de la Vega and Steigenga reveal the story of how this coalition came to be, the obstacles they faced, their growing pains, and their accomplishments which include over $\$ 883,044$ estimated value in yearly services rendered on an annual budget of just over $\$ 200,000$ (p.152).

One significant aspect of Against the Tide is Lazo de la Vega and Steigenga's place within the book's narrative. Steigenga helped found both Corn Maya Inc. and the El Sol center itself and he continues to invest himself in the operation of these institutions. Likewise, Lazo de la Vega has served as the president of the Corn Maya Inc. student group at Florida Atlantic University. This positionality allowed them unparalleled access to the internal dynamics of the center and the coalitions that built it. The authors, though, remain committed to an empirical analysis of the processes they witnessed and helped shape. Their participant-observation methodology is also corroborated with newspaper articles, interviews with diverse individuals with a stake in the process, as well as the transcripts of various speeches and Jupiter town meetings. The text is written in accessible language, likely for the benefit of an intended audience from diverse backgrounds and educational levels.

Nevertheless, Against the Tide could still be enhanced. The project may have benefited from a greater temporal distance from the creation of El Sol in order to see how changing political winds, time, and changing personnel/ members would have impacted the evolution of the center. Also, while the authors do describe the obstacles faced by pro-center coalitions, the book could have further analyzed the structural reasons why other day labor centers struggle to replicate El Sol's success.

This book tackles some of the central theoretical concerns of assimilation theory, immigrant incorporation, bonding and bridging social capital, immigration studies, citizenship studies, local governance, labour studies, and even social movements. Consequently, Against the Tide is a contribution to many academic disciplines and fields. Scholars in these areas of study would benefit greatly from reading this text. Furthermore, local politicians dealing with increased migration or conflict over day labor, activists, community advocates, and trade unionists working to organize migrant workers could gain practical knowledge in the pursuit of their interests.

Over all, I consider this book to be indispensible for anyone interested in immigration. Against the Tide is a complicated, compelling, measured account 
that empirically proves its claims. Lazo de la Vega and Steigenga show the reader the tribulations affecting both migrant and non-migrant residents of Jupiter when relating to migration. The authors further demonstrate how El Sol surpassed its own proposed goals in resolving what were localized standard-of-living issues. Perhaps most importantly, however, the book offers a tested, concrete solution to some of the many problems faced by migrants and the communities they call home.

\section{Notes}

1 The authors discuss at length the negative effects of local ordinances targeting migrants such as the Hazelton Illegal Immigration and Reform Act of 2006. Those impacts include the closing of local businesses due to the departure of migrants, the cost of legal fees in defense of unconstitutional policy provisions, and alienating migrant communities from the local government and police. See pgs. 149-151. 